\title{
Can we produce an image of bacteria with radiopharmaceuticals?
}

\author{
A. Signore • C. D'Alessandria • E. Lazzeri • R. Dierckx
}

Published online: 8 April 2008

(C) The Author(s) 2008

\section{Introduction}

Bacterial infection is nowadays one of the major causes of morbidity and mortality not only in developing countries but globally. Tuberculosis and multi-drug resistant bacteria are increasing and challenge the diagnostic approaches, the therapeutic schemes and the control of infection. Early diagnosis of infection and capacity to distinguish between bacterial and sterile inflammation is very important to efficiently treat patients and prevent the complications of pathology. Most infections are diagnosed by clinical history, physical examination, laboratory tests, identification of pathogens in body fluids and biopsies and by imaging techniques. There is a substantial difference in the use of non-nuclear medicine imaging techniques and the use of radionuclide techniques. The anatomical imaging

This Editorial commentary refers to the article http://dx.doi.org/ 10.1007/s00259-007-0671-3.

\section{A. Signore $\cdot$ C. D'Alessandria \\ Nuclear Medicine Unit, 2nd Faculty of Medicine, \\ Sapienza University of Rome, \\ Rome, Italy}

\section{A. Signore $\cdot$ R. Dierckx}

Nuclear Medicine and Molecular Imaging Department, University Medical Center Groningen, University of Groningen, Groningen, The Netherlands

\section{E. Lazzeri}

Nuclear Medicine Unit, University of Pisa,

Pisa, Italy

\author{
A. Signore $(\bowtie)$ \\ Nuclear Medicine, Ospedale S.Andrea, \\ Via di Grottarossa 1035, \\ 00189 Roma, Italy \\ e-mail: alberto.signore@uniroma1.it
}

techniques such as plain radiography, ultrasonography and computed tomography are sensitive mainly in chronic stages of infection when there are significant anatomical changes. The detection of infection by nuclear medicine techniques relies on the physiological and biochemical changes at the site of lesions, which manifest much prior to the appearance of the anatomical changes.

Nuclear medicine has therefore contributed in the last years in the development of several radiopharmaceuticals, used like non-invasive tools, to discriminate between infection and sterile inflammation. However, none of these are "infection specific" because sensitivity and specificity can differ according to the type of infection, to the type of micro-organism, to the infection site and to the host clinical conditions/response. The number of micro-organisms available for targeting seems to be a major discriminating factor for nuclear medicine techniques. The paper by Akhtar and colleagues [1], published in this issue of the journal, describes the relation between bacterial number and ${ }^{99 \mathrm{~m}}$ Tc-UBI $29-41$ uptake in mice. This provides important information about the specificity of this radiopharmaceutical but disappointingly evidences that it is difficult to discriminate between $2 \times 10^{4}$ and $2 \times 10^{6}$ bacteria, in this model, and it is probably difficult to image less than $2 \times 10^{4}$ bacteria, at least in a mouse. The question, therefore, arises about the minimum number of bacteria that can be detected in vivo, this being a relevant question to answer before routine clinical application of bacterial imaging in man.

\section{Radiopharmaceuticals for imaging bacteria}

Many radiopharmaceuticals have been reported so far to detect and locate infection. These are very sensitive but do not show high specificity in the discrimination between 
bacterial infection and sterile inflammation. This has been clearly summarised by Welling and colleagues [2] in a recent letter in reply to an editorial of G. Lucignani [3].

There is now a wide range of radiolabelled antimicrobial agents that are undergoing evaluation.

The first group consists of radiolabelled antibiotics such as ${ }^{99 \mathrm{~m}} \mathrm{Tc}$ - or ${ }^{18} \mathrm{~F}$-ciprofloxacin [4-9], ${ }^{99 \mathrm{~m}} \mathrm{Tc}$-sparfloxacin [10], ${ }^{99 \mathrm{~m}} \mathrm{Tc}$-ceftizoxime $[11,12]$ and ${ }^{18} \mathrm{~F}$-fleroxacin [13], anti-fungal agents such as ${ }^{99 \mathrm{~m}} \mathrm{Tc}$-fluconazole and ${ }^{99 \mathrm{~m}} \mathrm{Tc}$ isoniazid [14] and the anti-Mycobacterium tuberculosis agent ${ }^{99 \mathrm{~m}} \mathrm{Tc}$-ethambutol [15]. The second group of radiopharmaceuticals for imaging infections is derived from the array of human anti-microbial peptides/proteins that binds to specific bacterial antigens [16], e.g. peptides derived from human lactoferrin [17], ubiciquidin $\left({ }^{99 \mathrm{~m}} \mathrm{Tc}\right.$ or ${ }^{18} \mathrm{~F}$ UBI) [18-23] and human neutrophil peptide $1-3\left({ }^{99 \mathrm{~m}} \mathrm{Tc}-\right.$ HNP1-3; members of the $\alpha$-defensins) [24]. In this group, we can also include bacteriophages that specifically target bacterial antigens [25]. The third group of radiopharmaceuticals is represented by vitamins and bacterial growth factors that are necessary for bacteria growth as well as for human cell growth: in particular vitamin $\mathrm{H}$, a group $\mathrm{B}$ vitamin, called biotin, that was labelled with ${ }^{111}$ In [26].

\section{${ }^{99 m}$ Tc-UBI 29-41}

The anti-microbial peptides have a wide distribution throughout the animal and plant kingdom. They are produced by phagocytes, epithelial and endothelial cells and other cell types providing protection against microbial attacks [27]. Their expression is induced upon contact with micro-organisms or microbial products like lipopolysaccharides or pro-inflammatory cytokines such as tumour necrosis factor- $\alpha$, interferon- $\gamma$ and interleukin- 1 and contributes to the innate resistance to infection. Although various anti-microbial peptides present different chemical structures, their mechanism of action is based on the interaction of the cationic charged domains of the peptides with the negatively charged surface of the outer membrane of the bacteria. Microbial membranes expose negatively charged phospholipids, e.g. lipopolysaccharide or teichoic acids, on their surface while mammalian cells segregate into the inner leaflet the lipids with negatively charged headgroups, thus explaining the poor binding of antimicrobial peptides to mammalian cells $[28,29]$. A range of human anti-microbial peptides/proteins have been investigated as radiopharmaceuticals for imaging of infections. Amongst these, ${ }^{99 \mathrm{~m}} \mathrm{Tc}$-labelled ubiquicidin $29-41$ peptide fragment $\left({ }^{99 \mathrm{~m}} \mathrm{Tc}-\mathrm{UBI}\right)$ is a cationic human anti-microbial peptide (MW $1.69 \mathrm{kDa}$ ) with the aminoacid sequence ThrGly-Arg-Ala-Lys-Arg-Arg-Met-Gln-Tyr-Asn-Arg-Arg and has six positively charged residues ( $5 \mathrm{Arg}+1 \mathrm{Lys})$. In animal studies, ${ }^{99 \mathrm{~m}} \mathrm{Tc}-\mathrm{UBI}$ labelled by direct method showed rapid visualisation of infections with Gram-positive and Gram-negative bacteria and little accumulation in sterile inflammation processes. ${ }^{99 \mathrm{~m}} \mathrm{Tc}$-labelled UBI $29-41$ preferentially binds to bacteria and fungi in vitro and accumulates at the site of infection in experimental animal studies with fast renal clearance with minimal hepatobiliary excretion and shows the ability to detect infection foci in humans [20]. As compared to radiolabelled antibiotics, this radiopharmaceutical shows much lower uptake (as T/B ratio) in infected lesions and this raises the question whether this is due to a higher specificity and lower nonspecific binding or whether it is due to the lower number of molecules bound per bacteria.

\section{Further remarks on studies with radiopharmaceuticals for imaging bacteria}

Given the previous considerations and by reviewing the literature, it emerges that it is still unclear whether it is possible to image bacteria in vivo with radiopharmaceuticals, particularly due to relatively low bacterial mass present in infection (can be less than $10^{6} \mathrm{CFU}$ ) and, by consequence, due to the low number of targeting sites. Indeed, there is very limited published evidence that radiopharmaceuticals for bacteria bind to infected sites in a dose-dependent manner in relation to the number of bacteria. Akthar and colleagues [1], in this issue of EJNM\&MI, try to answer this question but it is not possible to make a comparison with other radiopharmaceuticals of this kind. This is due, in part, to the difficulty of planning similar in vivo experiments, considering the fast bacterial doubling time in vivo, different biodistribution, affinity and specific activity of radiopharmaceuticals.

Overall, we lack basic studies to clearly prove the mechanism of action and binding of these radiopharmaceuticals to bacteria. As an example, the use of in vivo displacement studies (typically using large amounts of unlabelled products) are limited because of bactericidal activity of these compounds that, in large amounts, may significantly reduce the number of target sites [30]. Furthermore, since the growth of bacteria is logarithmic, it is possible to calculate the theoretical number of bacteria only up to 1 or $2 \mathrm{~h}$ after injection in animal models and therefore the radioactivity associated to bacteria at site of infection. In many papers, images have been acquired $4 \mathrm{~h}$ or even $24 \mathrm{~h}$ after bacterial inoculation.

\section{What is the minimum number of bacteria that we can image?}

In theory, it is possible to calculate the number of labelled molecules of some radiopharmaceuticals bound to bacteria 
at the site of infection. This can be calculated on the basis of the molecular weight and specific activity of the radiopharmaceutical, the number, size and surface-tovolume ratio of bacteria. The specific activity of most anti-microbial radiopharmaceuticals can be obtained from data published by different authors in the literature as well as the number of bacteria at the time of imaging and the accumulated radioactivity at the site of injection (Table 1). Because of the small size of the majority of bacteria that are no larger than the average of eukaryotic cells $(<20 \mu \mathrm{m})$, all bacteria have a large surface-to-volume ratio varying from about 3:1 (for bacteria with diameter of $2 \mu \mathrm{m}$ ) to $0.3: 1$ (for bacteria with diameter of $20 \mu \mathrm{m}$ ). This is an advantage if the binding site of radiopharmaceuticals is located on the cell surface. Bacteria volume and mass are more difficult to calculate and vary according to shape and size of bacteria. For example, Staphylococcus aureus has an average volume of about $1.76 \mu^{3}(0.5-1 \mu \mathrm{m}$ cell diameter $)$ while Mycobacterium tuberculosis has a volume of about $8.4 \mu \mathrm{m}^{3}$ (2-4 $\mu \mathrm{m}$ in length and $0.2-0.5 \mu \mathrm{m}$ in width). The weight of an average bacterium is reported to be about $5-15 \times 10^{-7} \mathrm{~g}$ [31]. Therefore, the available targeting mass of $10^{6}$ $S$. aureus is about $1.76 \mathrm{~mm}^{3}$, very small if compared to the mass of $10^{6}$ granulocytes which is about $1.4 \mathrm{~cm}^{3}(4 /$ $3 \pi r^{3}$ for $14 \mu \mathrm{m}$ diameter), 1,000-fold more than bacteria. Despite surface binding sites in bacteria being 10- to 50fold more than those present on granulocytes, it is difficult to believe that we can image such a small mass of bacteria with the available technology.

If we then calculate the number of bound molecules of radiopharmaceutical per single bacteria, a wide range of results appear (Table 1) and this suggests that, at least for some radiopharmaceuticals, the majority of radioactivity accumulated at the site of infection is non-specifically bound to bacteria and is due to the presence of plasma leakage from capillaries.

\section{Host response to microbial infection}

Another aspect that we should consider when attempting to image bacteria is that infection associated with prosthetic joints is typically caused by micro-organisms that grow in biofilms. Within biofilms, micro-organisms are enclosed in a polymeric matrix and develop into an organised, complex community with structural and functional heterogeneity. In the biofilm, microbes are protected from anti-microbial agents and host immune responses [32, 33]. In these conditions, the radiolabelled anti-microbial agents cannot interact with bacteria but only with the extra-cellular matrix giving information not suitable for specific antibiotic treatment of the prosthetic infection.

Last but not least, it is necessary to consider the host response to an infection process. Under the same conditions (with same number of bacteria), bacteria growth is dependent on host reaction, particularly on macrophage and monocyte response. These cells can control infection spreading in a fast or slow way in accordance with their number and functionality that change between different living beings and different tissues and psychological/ metabolic condition of the host. In some cases, associated oedema and vascular leakage can also be readily induced by bacterial toxins produced by a very low number of bacteria (thus increasing the possibility of non-specific accumulation of radiopharmaceuticals) and, in other cases, a large number of bacteria may give rise only to a minor host response. Some radiolabelled anti-microbial agents

Table 1 Calculation of number of living bacteria at $4 \mathrm{~h}$ after injection in animal models and activity/bacteria of some radiolabelled antimicrobials

\begin{tabular}{|c|c|c|c|c|c|c|c|}
\hline $\begin{array}{l}\text { Radiolabelled } \\
\text { anti-microbial }\end{array}$ & $\begin{array}{l}\text { Specific } \\
\text { activity } \\
\text { (mean) }\end{array}$ & $\begin{array}{l}\mu \mathrm{Ci} \text { per } \\
\text { molecule }\end{array}$ & $\begin{array}{l}\text { Type of } \\
\text { bacteria }\end{array}$ & $\begin{array}{l}\text { Calculated no. of bacteria } \\
\text { at site of infection at } \\
\text { time of imaging }\end{array}$ & $\begin{array}{l}\mu \mathrm{Ci} \text { per } \\
\text { bacteria }^{\mathrm{b}}\end{array}$ & $\begin{array}{l}\text { Calculated bound } \\
\text { molecules per } \\
\text { bacteria }\end{array}$ & $\begin{array}{l}\text { Reference } \\
\text { used for } \\
\text { analysis }\end{array}$ \\
\hline 99m Tc-UBI (29-41) & $5 \mu \mathrm{Ci} / \mu \mathrm{g}$ & $9 \times 10^{-14}$ & S. aureus & $2.58 \times 10^{8}$ & $4.18 \times 10^{-9}$ & $2,000,000$ & {$[1,22]$} \\
\hline${ }^{99 \mathrm{~m}}$ Tc-UBI (29-41) & $6.7 \mu \mathrm{Ci} / \mu \mathrm{g}$ & $4 \times 10^{-16}$ & S. aureus & $1.17 \times 10^{12}$ & $5.1 \times 10^{-12}$ & 10,000 & {$[21]$} \\
\hline${ }^{99 \mathrm{~m}} \mathrm{Tc}$-ciprofloxacin & $5 \mu \mathrm{Ci} / \mu \mathrm{g}$ & $29.7 \times 10^{-20}$ & S. aureus & $5 \times 10^{8}$ & $3.55 \times 10^{-8}$ & $241 \times 10^{8}$ & [8] \\
\hline${ }^{99 \mathrm{~m}}$ Tc-ciprofloxacin & $5 \mu \mathrm{Ci} / \mu \mathrm{g}$ & $32 \times 10^{-20}$ & S. aureus & $10^{7}$ & $1.59 \times 10^{-9}$ & $105 \times 10^{9}$ & [6] \\
\hline${ }^{99 m}$ Tc-sparfloxacin & $5.4 \mu \mathrm{Ci} / \mu \mathrm{g}$ & $4 \times 10^{-15}$ & S. aureus & $5.83 \times 10^{11}$ & $7.4 \times 10^{-11}$ & 900,000 & {$[10]$} \\
\hline${ }^{99 \mathrm{~m}} \mathrm{Tc}$-isoniazid & $5.4 \mu \mathrm{Ci} / \mu \mathrm{g}$ & $1 \times 10^{-15}$ & S. aureus & $5.85 \times 10^{15}$ & $1.6 \times 10^{-14}$ & 300 & [14] \\
\hline
\end{tabular}

Calculations have been made on the basis of information published by authors and of personal communication in the case of Tc-UBI kindly provided by Dr. M. Welling

${ }^{\text {a }}$ This has been calculated using the following formula $b=B \times 2^{n}$, where $b$ is the number of bacteria at time of imaging, $B$ is the number of injected bacteria $(\mathrm{CFU} / \mathrm{ml})$ and $n$ is the number of generations of bacteria, calculated on the basis of time interval occurred between injection and imaging. The number $n$ is different for each type of bacteria

${ }^{b}$ This has been obtained by calculating the ratio between the \%ID at site of infection reported in each paper and the number of bacteria at site of infection at the time of imaging 
have also shown to bind to monocytes and granulocytes [34-37].

From these considerations, it appears that we still need to investigate many basic aspects to better understand the mechanisms of binding and accumulation of radiopharmaceuticals to bacteria in the hope of finding a specific and reliable tool for imaging infection that can be used in clinical settings together or instead of the scintigraphy with radiolabelled autologous leukocytes or radiolabelled monoclonal antibodies to granulocyte antigens.

Open Access This article is distributed under the terms of the Creative Commons Attribution Noncommercial License which permits any noncommercial use, distribution, and reproduction in any medium, provided the original author(s) and source are credited.

\section{References}

1. Akhtar MS, Khan ME, Khan B, Irfanullah J, Afzal MS, Khan MA, et al. An imaging analysis of $99 \mathrm{mTc}-\mathrm{UBI}(29-41)$ uptake in $S$. aureus infected thighs of rabbits on ciprofloxacin treatment. Eur J Nucl Med Mol Imaging 2008. DOI 10.1007/s00259-007-0671-3.

2. Welling M, Stokkel M, Balter J, Sarda-Mantel L, Meulemans A, Le Guludec D. The many roads to infection imaging. Eur J Nucl Med Mol Imaging 2008;35. DOI 10.1007/s00259-007-0695-8.

3. Lucignani G. The many roads to infection imaging. Eur J Nucl Med Mol Imaging. 2007;34(11):1873-7.

4. Britton KE, Wareham DW, Das SS, Solanki KK, Amaral H, Bhatnagar A, et al. Imaging bacterial infection with ${ }^{99 \mathrm{~m}} \mathrm{Tc}-$ ciprofloxacin (Infecton). J Clin Pathol. 2002;55:817-823.

5. Hall AV, Solanki KK, Vinjamuri S, et al. Evaluation of ${ }^{99 \mathrm{~m}} \mathrm{Tc}-$ Infecton, a novel agent for detecting site of infection. J Clin Pathol. 1996;51:215-219.

6. Sarda L, Saleh-Mghir A, Peker C, Meulemans A, Crémieux AC, Le Guludec D. Evaluation of $(99 \mathrm{~m})$ Tc-ciprofloxacin scintigraphy in a rabbit model of Staphylococcus aureus prosthetic joint infection. J Nucl Med. 2002;43(2):239-45.

7. Sarda L, Crémieux AC, Lebellec Y, Meulemans A, Lebtahi R, Hayem $\mathrm{G}$, et al. Inability of $99 \mathrm{mTc}$-ciprofloxacin scintigraphy to discriminate between septic and sterile osteoarticular diseases. J Nucl Med. 2003;44(6):920-6.

8. Siaens RH, Rennen HJ, Boerman OC, Dierckx R, Slegers G. Synthesis and comparison of Tc-99m-enrofloxacin and Tc-99mciprofloxacin. J Nucl Med. 2004;45(12):2088-94.

9. Langer O, Brunner M, Zeitlinger M, Ziegler S, Müller U, Dobrozemsky G, et al. In vitro and in vivo evaluation of [18F] ciprofloxacin for the imaging of bacterial infections with PET. Eur J Nucl Med Mol Imaging. 2005;32(2):143-50.

10. Singh AK, Verma J, Bhatnagar A, Ali A. Tc-99m labeled sparfloxacin: a specific infection imaging agent. W J Nucl Med. 2003;2(2):103-109.

11. Martin-Comin J, Soroa V, Rabiller G, Galli R, Cuesta L, Roca M. Diagnosis of bone infection with $99 \mathrm{mTc}$-ceftizoxime. Rev Esp Med Nucl. 2004;23(5):357.

12. Gomes Barreto V, Rabiller G, Iglesias F, Soroa V, Tubau F, Roca M, et al. $99 \mathrm{mTc}$-ceftizoxime scintigraphy in normal rats and abscess induced rats. Rev Esp Med Nucl. 2005;24(5):312-8.

13. Fischman AJ, Livni E, Babich J, Alpert NM, Liu YY, Thom E, et al. Pharmacokinetics of 18F-labeled fleroxacin in rabbits with Escherichia coli infections, studied with positron emission tomography. Antimicrob Agents Chemother. 1992;36(10):2286-92.
14. Singh AK, Verma J, Bhatnagar A, Sen S, Bose M. Tc-99 isoniazid: a specific agent for diagnosis of tuberculosis. W J Nucl Med. 2003;2:292-305.

15. Causse JE, Pasqualini R, Cypriani B, Weil R, Van der Valk R, Bally $\mathrm{P}$, et al. Labelling of ethambutol with $99 \mathrm{mTc}$; using a new reduction procedure. Pharmacokinetic study in the mouse and rat. Int J Rad Appl Instrum (A). 1990;41(5):493-6.

16. Lupetti A, Welling MM, Pauwels EK, Nibbering PH. Radiolabelled antimicrobial peptides for infection detection. Lancet Infect Dis. 2003;3(4):223-9.

17. Welling MM, Lupetti A, Balter HS, Lanzzeri S, Souto B, Rey AM, et al. $99 \mathrm{mTc}$-labeled antimicrobial peptides for detection of bacterial and Candida albicans infections. J Nucl Med. 2001;42(5):788-94.

18. Lupetti A, Pauwels EKJ, Nibbering PH, Welling MM. 99mTcantimicrobial peptides: promising candidates for infection imaging. Q J Nucl Med. 2003;47:258-45.

19. Nibbering PH, Welling $M$, van den Broek PJ, Pauwels EKJ. Radiolabelled antimicrobial peptides for imaging of infection: a review. Nucl Med Comm. 1998;19:1117-21. Dec.

20. Meléndez-Alafort L, Rodrìguez-Cortés J, Ferro-Flores G, Murphy CA, Herrera-Rodrìguez R, Martìnez-Duncker C. Biokinetics of ${ }^{99 \mathrm{~m}}$ Tc-UBI in humans. Nucl Med Biol. 2004;31:373-9.

21. Akhtar MS, Iqbal J, Khan MA, Irfanullah J, Jehangir M, Khan B, et al. 99mTc-labeled antimicrobial peptide ubiquicidin (29-41) accumulates less in Escherichia coli infection than in Staphylococcus aureus infection. J Nucl Med. 2004;45:849-856.

22. Welling MM, Paulusma-Annema A, Balter HS, Pauwels EK, Nibbering PH. Technetium-99m labelled antimicrobial peptides discriminate between bacterial infections and sterile inflammations. Eur J Nucl Med. 2000;27:292-301.

23. Zijlstra S, Gunawan J, Freytag C, Burchert W. Synthesis and evaluation of fluorine-18 labelled compounds for imaging of bacterial infections with pet. Appl Radiat Isot. 2006;64(7): $802-7$.

24. Welling MM, Nibbering PH, Paulusma-Annema A, Hiemstra PS, Pauwels EK, Calame W. Imaging of bacterial infections with 99mTc-labeled human neutrophil peptide-1. J Nucl Med. 1999;40:2073-80.

25. Rusckowski M, Gupta S, Liu G, Dou S, Hnatowich DJ. Investigations of a $(99 \mathrm{~m}) \mathrm{Tc}-$ labeled bacteriophage as a potential infection-specific imaging agent. J Nucl Med. 2004;45(7): 1201-8.

26. Lazzeri E, Erba P, Perri M, Tascini C, Doria R, Giorgetti J, et al. The scintigraphic imaging of vertebral osteomyelitis with ${ }^{111} \mathrm{In}$ biotin. Spine 2008 (in press).

27. Zasloff M. Antimicrobial peptides of multicellular organism. Nature. 2002;415:389-95.

28. Cudic M, Otvos L. Intracellular targets of antimicrobial peptides. Current Drug Targets. 2002;3:101-6.

29. Hancock REW, Rozek A. Role of membrane in the activities of antimicrobial cationic peptides. FEMS Microbiol Lett. 2002;206:143-9.

30. Alexander K, Drost WT, Mattoon JS, Kowalski JJ, Funk JA, Crabtree AC. Binding of ciprofloxacin labelled with technetium Tc $99 \mathrm{~m}$ versus $99 \mathrm{mTc}$-pertechnetate to a live and killed equine isolate of Escherichia coli. Can J Vet Res. 2005;69 (4):272-7.

31. Sistrom WR. Microbial life. New York: Holt, Rinehart and Winston; 1969.

32. Chandra J, Kuhn DM, Mukherjee PK, Hoyer LL, McCormick T, Ghannoum MA. Biofilm formation by the fungal pathogen Candida albicans: development, architecture, and drug resistance. J Bacteriol. 2001;183(18):5385-94.

33. Zimmerli W, Trampuz A, Ochsner P. Prosthetic-joint infections. N Engl J Med. 2004;351:1645-54. 
34. Bounds SJ, Nakkula R, Walters JD. Fluoroquinolone transport by human monocytes: characterization and comparison to other cells of myeloid lineage. Antimicrob Agents Chemother. 2000;44 (10):2609-14. Oct.

35. Walters JD, Zhang F, Nakkula RJ. Mechanisms of fluoroquinolone transport by human neutrophils. Antimicrob Agents Chemother. 1999;43(11):2710-5. Nov.
36. Walters JD, Nakkula RJ. Ciprofloxacin transport by chemoattractant-activated polymorphonuclear leukocytes: regulation by priming and protein kinase C. Antimicrob Agents Chemother. 2003;47(10):3345-8. Oct.

37. Prokesch RC, Hand WL. Antibiotic entry into human polymorphonuclear leukocytes. Antimicrob Agents Chemother. 1982;21 (3):373-80. Mar. 